\title{
Sustainable Development of Agricultural Sector: Democratic Profile Impact Among Developing Countries
}

\author{
Oleksii Lyulyov $^{1}$, Tetyana Pimonenko ${ }^{1}$, Natalia Stoyanets ${ }^{2} \&$ Nataliia Letunovska $^{1}$ \\ ${ }^{1}$ Department of Marketing, Sumy State University, Sumy, Ukraine \\ ${ }^{2}$ Department of Managment, Sumy National Agrarian University, Sumy, Ukraine \\ Correspondence: Oleksii Lyulyov, Department of Marketing, Sumy State University, 40007, Sumy, Ukraine. Tel: \\ 380-66-790-5720. E-mail: alex_lyulev@econ.sumdu.edu.ua
}

Received: November 26, 2019

Accepted: December 14, 2019

Online Published: December 22, 2019

doi:10.5430/rwe.v10n4p97

URL: https://doi.org/10.5430/rwe.v10n4p97

\begin{abstract}
The bullet point of Sustainable Development Goals (SDGs) 2030 is improving of countries food security through decreasing of hungry level and providing equal conditions for food to everyone. Besides, according to the findings the issues with hungry index could be solved through developing the agricultural sector corresponding of SDGs principals. The findings showed that the agricultural sector is start point of decreasing the hungry. The authors proved the type of the political regime had impact on the efficiency of achieving of SDGs and countries' food security. The hypothesis of investigation was checking the relationship between political profile of the countries and level of sustainable development of the agricultural sector (ASI). The assessment of the relationship between average level of ASI and countries' democratic profile (democracy level of public relations) for 28 countries of Post-Soviet bloc proved the non-existence of differences between countries with authoritarian and transitional regimes opposed to other political regimes (imperfect and full democracy). The authors allocated three segments of countries: authoritarian and transitional regimes, imperfect democracy and full-fledged democracy. The findings proved the hypothesis that democracy level had a statistically significant impact on the average level of ASI. Using the bivariate and multivariate models the authors empirically proved that the democracy level increase by 1-point leads to the increase of the target index by 0.087 points for countries with authoritarian and transitional regimes (to which Ukraine belongs). Thus, the transition to a more democratic model of the political regime will partially offset the threats to food security.
\end{abstract}

Keywords: ANOVA, democracy, food security, model, segments

\section{Introduction}

The issues of food security through the implementation of sustainable development principles in the agricultural sector are the priority and are taken on a global dimension. Thus, the transformation from Millennium Sustainable Development Goals to Sustainable Development Goals 2030 lead to change focus to the issues on decreasing hungry and increasing of food security. One should mention that many scientists and experts define food security as environmental friendliness of food, which is a shift in focus from food shortages (i.e, to satisfy hunger) to increase access to quality and safe food. These transformational processes provoke the necessity to estimate the relationship between food security, the level of income and the country's political environment, moving away from the hunger index, which is the main indicator of poverty in the country. The number of scientists is exploring the impact of the institutional environment on the sustainable development of the agricultural sector, the main index of which is the level of food security, physical, social, emotional and cognitive development of society throughout life (Pérez-Escamilla, 2017).

The sustainable development of the agricultural sector needs to implement the relevant political decisions which relate to the quality of the institutional environment. At the same time, the scientists highlighted that democracy is the most effective form of the political regime to enlarge the principle of sustainable development into all economic sectors, including the agricultural sector.

Afoaku O.G. (2005) defines that the full democracy is a key driver of the sustainable development which leads to the trust level's increasing to the government from the society and indirect to decreasing of the hunger level, mortality, 
poverty, minimizes possible socio-, ecological and economic conflicts. Harris K. (2014) distinguishes three main components which influence food security growth through the implementation of the sustainable development principles of the agrarian sector in the economy: the level of democracy; rights and freedom of speech; efficiency of political institutions functioning. Moreover, Harris argues that democratic institutions help to reduce hunger by creating fair and open competition, which encourages compliance with the principles of sustainable agricultural and industrial development (Harris, 2014) Thus, countries with high poverty and hunger, low food security index have a higher probability of mass displeasure in society than countries with above-average indices have.

Thus, one of the main tasks of the country's political institutes is to support food security, to form agricultural infrastructure in accordance with the principles of sustainable development, by providing free access to markets, agriculture subsidizing, or food prices timely regulation. The established system of institutions must respond promptly to the needs of the community and adapt to new challenges. At the same time, timely provision of priority public needs leads to the increased social security and confidence in the authorities.

Rossignoli D. and Balestri S. (2017) define that the political regime has a statistically significant impact on the food security level of the country, which is a key index of the sustainable development of the agricultural sector in the economy. At the same time, the authors find that in countries with full democracy, implementation of the principles regarding the sustainable development of the agricultural sector of the economy is more effective, so that is why it increases the level of food security and decreases the hunger index.

Blaydes L. and Kayser M.A. (2011) in their study observe the relationship between political regimes and calories consumed in the country. They empirically confirm that democracy and hybrid political regimes, which combine elements of autocracy, more effectively transform economic growth outcomes, than increase the consumed calorie at autocracy. The authors argue that democracy is a more effective form of the political system than a hybrid political regime.

In (Swinnen \& Vandevelde, 2018), scientists note that the relevant structural changes in the economic development change the advantages and benefits of different stakeholder groups, thereby stimulating an increase in the political openness of government. In turn, it requires the government to form an effective political regime and timely adjustment of the political and economic equilibrium (Anderson, 1995; de Gorter, H. \& Swinnen, J., 2002; Swinnen \& Vandevelde, 2018).

It should be noted that there are two conflicting views on the relationship between the sustainable development of the agricultural sector and the level of democracy: in terms of comparability, democracy has a positive impact on the sustainable economic development of countries; from the viewpoint of the conflict situation, democracy adversely affects the countries' sustainable economic development (De Haan, J. \& Siermann, Clemens L.J., 1996).

Thus, supporters of the conflict theory use as an example the countries with authoritarian political regimes (Hong Kong, Singapore, and Taiwan) and have achieved rapid growth in all sectors of the economy, including the agricultural one (Nelson, Michael A. \& Singh, Ram D., 1998) Supporters of the first concept exemplify the ineffectiveness of the authoritarian regime in African countries. It should be noted that both approaches are based on the question which political regime provides property rights, reduces consumption, supports the implementation of timely political decisions that lead to the sustainable development of economic sectors. A group of researchers in work (Olper et al., 2013), analysing the impact of all democratic reforms since the 1960s based on empirical results, has shown that, on average, democratization creates an impetus for the development of the agricultural sector of the economy.

According to Quinn D.P. and Woolley J.T. (2001), leaders in the democratic political regime have been lobbying for a policy for the development of an agrarian sector that is in the interests of the middle class. This, in turn, leads to widening gaps in the income of different stakeholder groups in the agricultural sector. Similarly, Henisz W.J. (2000) emphasizes that the democratic system involves more stakeholders in political decision-making compared to a dictatorial political regime.

According to Rodrik's work (1999, 2000), the democratic regime creates favourable conditions for minimizing the scale of possible external shocks. Thus, the author argues that, with full democracy, there is a rapid response to possible conflicts caused by external shocks at the expense of a well-established system of communication between the government and the main stakeholders, while limiting the uneven distribution of income between them.

The results of the analysis of the scientific literature make it possible to conclude that the current scientific practice does not have the established approach to determining either a force of influence of the democracy level on the sustainable development of the agricultural sector in the developing countries, or to identifying the existing 
relationships between the political regime and the sustainable development of the agricultural sector in the economy. Thus, many scientists study the impact of the democracy level on the macroeconomic stability of the country (Bilan et al., 2019; Yevdokimov et al., 2018; Dkhili, 2018; Dkhili \& Dhiab, 2019), economic development (Baklouti \& Boujelbene, 2018; Kim \& Heshmati, 2019; Acemoglu et al., 2019), analysing the development of economic sectors in the aggregate. Another group of scientists, on the contrary, is engaged in analysing the drivers regarding the sustainable development of particular sectors of the economy, including the agricultural sector (Prasad et al., 2017; Li et al., 2018; Altieri, 2018; Vasylieva et al, 2019; Bilan et al, 2019). However, they avoid an analysis of the impact of the political institutions functioning and political regimes in the country. The third group of researchers is investigating the sustainable development of the agricultural sector more in developed countries and less in developing countries (Awokuse \& Xie, 2015; Yang et al., 2018). However, in the writings of these scientists, as a rule, there is no analysis and empirical assessment of the impact made by the institutional environment on the sustainable development of the agricultural sector of the economy.

\section{Method}

It should be noted that there is no established and universally recognized division of countries by level of democracy or democratic profile. Thus, in order to identify the relationship between a democratic profile and economic instability, Mathonnat C. and Minea A. (2018) use the Random effect model to analyse panel data from 140 countries for 1975-2007. Turkish scientists in (Bozkurt et al., 2018) study the impact of the Freedom House Democracy Index on the country's GDP using cointegration analysis and the single root method. Feng (1997) uses the least-squares method to describe the power of the influence made by the level of democracy and the effectiveness of political institutions on the economic growth of economic sectors. In (Leblang, 1996), the author analyses cross-national panel data and concludes that full-fledged democracy has a positive impact on the country's economic growth. It should be noted that the results of the analysis of the scientific literature indicate that there is a wide range of economic and mathematical tools to assess the impact of democracy on the development of economic sectors. At the same time, it is necessary to analyse the strength of the relationship between the variables and the result index before the stage to assess the impact of the indices. In the framework of this study, the relationship between country's democratic profile (variable parameters) and the level of sustainable development of the agrarian sector (result indicator) was analysed.

Thus, based on the systematization of scientific researches it was found that the ANOVA method was the most widely used in this context. This method is most commonly implemented to correlate variables in the analysis of agricultural sector development and functioning, marketing research, and more. It should be noted that the ANOVA method is used by scientists to analyse genetic and environmental impacts on agricultural product quality (Lewontin, 1974).

In addition, ANOVA has become widespread in analysing the factors affecting the country's hunger index and food security. Thus, this method was used by scientists Maxwell et al. (1999), Kaiser et al. (2002), Hackett et al. (2010), Allen M. W. \& Wilson M. (2005). Noted, that ANOVA used to identification the average of variables in two or more don't related groups. Besides, this method used only for three or more variables.

Therefore, in the first stage, the information base of the countries' democratic profiles (DEM) indices was formed. In this study, the starting point for the calculations was the data from the UK-based Economist Intelligence Unit (2018), as well as Freedom House (2018) and Polity IV (2018). In the second stage, the data of the indexes of the estimation of the democratic profiles of the countries by the data of Freedom House, Polity IV and Economist Intelligence Unit was filtered by eliminating the interdependent parameters based on the developed correlation matrices. In the third stage, the statistically significant difference in average levels of the agricultural sector sustainable development (ASI) for the selected democracy profiles was estimated according to the Economist Intelligence Unit using the Bartlett test. In the fourth stage, the countries were segment based on the Tukey test. It determines whether the variables are additively related to the parameter under study. This method is applied if there is no replication of values in the data set (the case where it is impossible to estimate the total non-additive regression structure completely). Statistics developed by Tukey have one degree of freedom providing the null hypothesis. In this regard, the Tukey test is called the test of one freedom degree.

In order to assess the strength of the democratic profiles influence on ASI countries, it is proposed to use bivariate and multivariate economic and mathematical models (Eq. 1 and 2) that considering the intensity of implementation of democratic profiles and the corresponding level of the country's social, ecological and economic development. 


$$
\begin{gathered}
A S I_{i t}=f\left(D E M_{i t}\right)=a_{0}+\sum_{i=1}^{n} b_{0} D E M_{i t}+\varepsilon_{t}, \\
A S I_{i t}=f\left(D E M_{i t}, X_{i t}\right)=a_{0}+\sum_{i=1}^{n} b_{0} D E M_{i t}+\sum_{i=1}^{n} c_{0} X_{i t}+\varepsilon_{t}
\end{gathered}
$$

where exogenous indices $(\mathrm{X})$ are additionally included in the multivariate model as explanatory variables:

- DEM - the democracy level of country i;

- GDP - the country's economic growth, which is defined as GDP per capita (it is established that the transition to a democratic regime, in the long run, will contribute to the GDP growth of the country);

- A is the area of agricultural land $(\mathrm{km} 2)$;

- $\quad \mathrm{P}$ is the population of the country (small countries are more prone to democracy).

The data for this research consists of a panel of 26 selected countries (Albania, Armenia, Azerbaijan, Belarus, Bulgaria, Croatia, Czech Republic, Estonia, Georgia, Hungary, Kazakhstan, Kyrgyzstan, Latvia, Lithuania, Moldova, Montenegro, Poland, Romania, Russia, Serbia, Slovakia, Slovenia, Tajikistan, Turkmenistan, Ukraine, Uzbekistan), based on the World Bank (2019).

\section{Results}

The most common methods to assess the democracy level in the country were developed by the agencies Freedom House, Polity IV, Economist Intelligence Unit. We should note that each methodology has an appropriate set of indices and criteria for the distribution of democracy in the country. The dynamics of the Freedom House Democracy Index is presented in Figure 1.
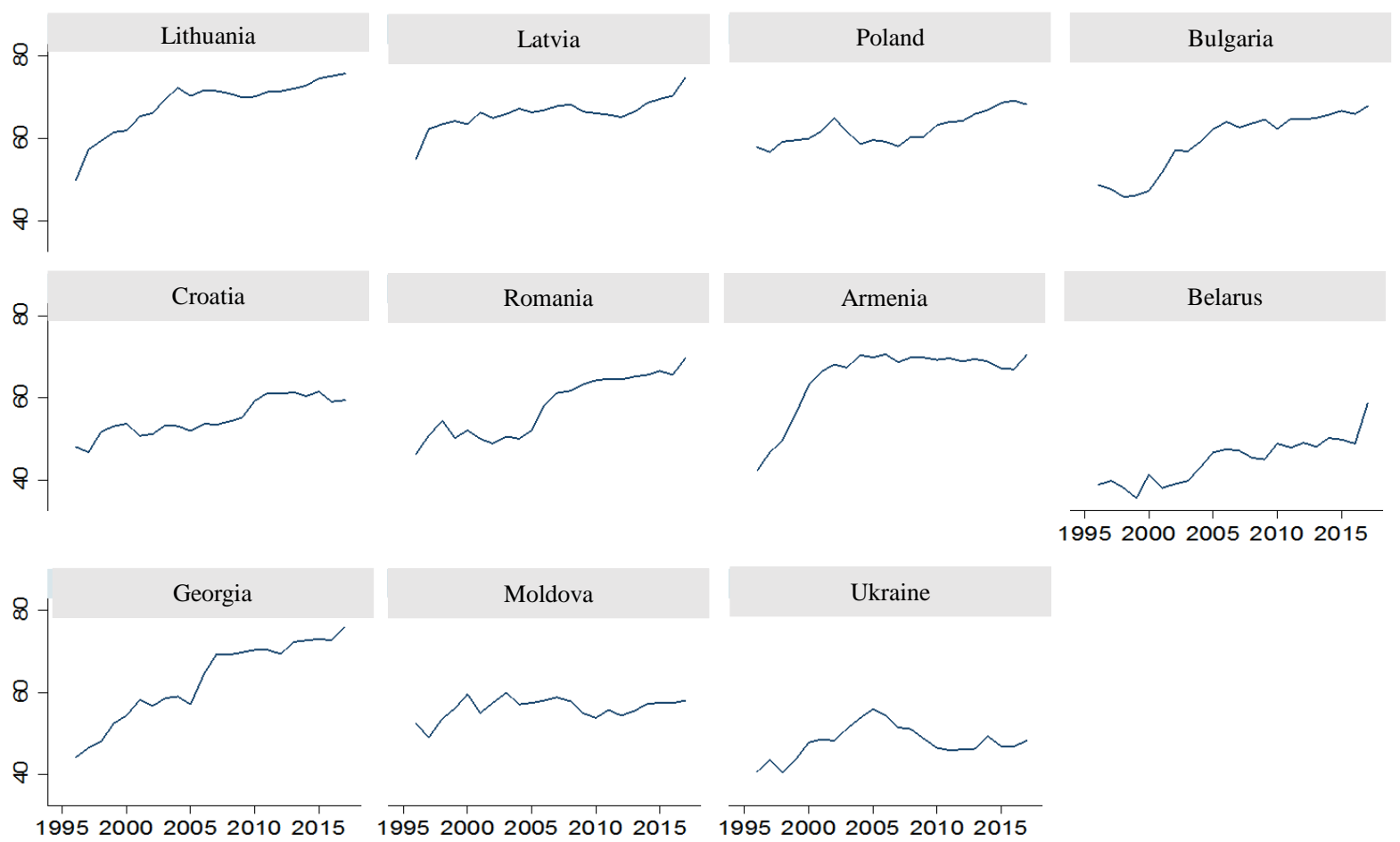

Figure 1. Democracy Index dynamics according to Freedom House (2018)

The results of the survey regarding the democracy index of the studied countries show that Estonia, the Czech Republic, Slovenia, Lithuania, Slovakia and Latvia had the highest level of democracy index in Freedom House in 2018. All these countries are in the free country group. At the same time, in 2018, the democracy index in Ukraine was 62 , which belongs to the group of partially free countries. It should be noted that the Democracy Index for Freedom House in 2018 in Ukraine increased by 5 points compared to 2013. The lowest Freedom House Democracy Index in Ukraine in 2014 was 55 points. 
The carried out correlation analysis regarding the generally recognized indices of the country's Democratic profile assessment of Freedom House, Polity IV and Economist Intelligence Unit confirms the existence of a close statistically significant $(\mathrm{p}<0.001)$ correlation between them, which causes the generation of similar results when using the indices in empirical studies.

Table 1. Assessment of the relationship between countries' Democratic profiles by Freedom House, Polity IV and Economist Intelligence Unit during 2006-2016

\begin{tabular}{cccc}
\hline $\begin{array}{c}\text { Methods to assess the democratic } \\
\text { profiles of the countries }\end{array}$ & Freedom House & Polity IV & $\begin{array}{c}\text { Economist } \\
\text { Intelligence Unit }\end{array}$ \\
\hline Freedom House & 1.000 & 0.879 & 0.823 \\
Polity IV & 0.879 & 1.000 & 0.823 \\
Economist Intelligence Unit & 0.823 & 0.823 & 1.000 \\
\hline
\end{tabular}

Source: calculated by the authors

Therefore, in the context of this study, a country-by-country classification of democracy investigated by the UK-based Economist Intelligence Unit is an index of the political regime.

The empirical results of calculations of the statistical significance regarding the average ASI levels difference by the selected democracy profiles according to the Economist Intelligence Unit are presented in Table 2.

Table 2. Assessment of the statistical significance of the average ASI levels difference by the democracy profiles according to the Economist Intelligence Unit

\begin{tabular}{ccccc}
\hline Variables & SS & MS & F & Prob > F \\
\hline Between the democratic profiles & 29.83 & 9.94 & 54.71 & 0.00 \\
In the democratic profiles & 43.44 & 0,18 & \\
Total & 73.28 & 0.30 & \\
\hline \multicolumn{4}{c}{ Bartlett's test } \\
\hline$\square^{2}$ & 72.64 & \\
Prob $>\square^{2}$ & 0.00 & \\
\hline
\end{tabular}

Source: calculated by the authors

The results presented in Table 2 show the descriptive statistics, including the average value, the standard deviation for the dependent variable (ASI level) for each group of independent variables: between democratic profiles; in democratic profiles; between democratic profiles and in democratic profiles.

The ANOVA model suggests that there is a statistically significant difference between the two groups. The significance level is $0.00(\mathrm{p}=0.00)$, which is below 0.05 . Therefore, there is a statistically significant difference in average ASI levels and democratic profiles.

The results of countries segmentation based on the Tukey test are presented in Table 3.

Table 3. Segmentation of countries by the demographic profile and ASI levels

\begin{tabular}{lccc}
\hline \multicolumn{1}{c}{ DEMOCRATIC PROFILE } & Contrast & $\mathrm{t}$ & $\mathrm{P}>|\mathrm{t}|$ \\
\hline Transitional and Authoritarian Regimes & -0.07 & -0.82 & 0.84 \\
Imperfect democracy and the Authoritarian regime & 0.63 & 9.54 & 0.00 \\
Full-fledged democracy and the Authoritarian regime & 1.14 & 6.24 & 0.00 \\
Imperfect democracy and the Transitional regime & 0.70 & 9.71 & 0.00
\end{tabular}


Full-fledged democracy and a transitional regime

Source: calculated by the authors.

John Tukey's test results showed that the ASI level was statistically and significantly higher in countries with a democratic profile - a full-fledged democracy compared to a group of countries with authoritarian $(1.14 \pm 0.18, \mathrm{p}=$ $0.00)$ and transitional $(1.21 \pm 0.18, \mathrm{p}=0.00)$ modes.

At the same time, there were no statistically significant differences between transitional and authoritarian regimes $(-0.07 \pm 0.08, p=0.84)$, which allowed the analysed countries to be divided into three segments according to the average ASI level and their democratic profile: authoritarian and transitional regimes; imperfect democracy; full-fledged democracy (Table 4).

Table 4. Segments of the democratic profiles considering ASI level

\begin{tabular}{cc}
\hline Segment & Countries \\
\hline SEGMENT 1: authoritarian and transitional \\
regimes & 2006-2016: Albania, Armenia, Azerbaijan, Belarus, Georgia, \\
& Kazakhstan, Kyrgyzstan, Russia, Tajikistan, Turkmenistan, Uzbekistan. \\
& 2013-2016 - Montenegro. 2011-2016 - Ukraine. \\
2006-2016: Bulgaria, Croatia, Estonia, Hungary, Latvia, Lithuania, \\
Moldova, Poland, Romania, Serbia, Slovakia, Slovenia. \\
2006-2012 Montenegro 2014-2016 Czech Republic. 2006-2010 \\
Ukraine. \\
SEGMENT 3: Full-fledged democracy
\end{tabular}

Source: Source: calculated by the authors

In Ukraine, for example, the change of the political regime in 2010 caused transformational shifts in the democratic profile (from imperfect to transitional democracy), which in turn provoked a widening gap between the AIS of Ukraine and the EU countries. The second and third segment countries (Czech Republic, Hungary, Latvia, Lithuania, Croatia, Poland, Serbia, Slovakia, Bulgaria, Slovenia, Romania and Estonia) with effective democratic institutions through the incentive and counterbalancing system, control the state power and implement an effective agricultural policy that keeps up the ASI level.

It should be noted that various types of direct payments are used to achieve the general objective of stabilizing incomes, preserving the environment, and improving food security. For example, Australia does not provide direct payments at all. The draft law on Agriculture in the USA also stopped direct payments and transformed government support into various types of insurance. Switzerland implements basic payment and payment for crops that require significant amounts of energy (e.g. oilseeds, legumes, sugar beets) in lowland areas; differentiation of payments for areas with natural handicaps, i.e. for mountainous areas and areas on steep slopes. Farming income stability in Japan is ensured by crop diversification. It means that the financial state support is addressed to producers who refocus the use of rice paddies from table rice to other crops (e.g. wheat, soybeans and rice fodder). The results from the assessment of the democratic profile impact strength on ASI countries are demonstrated in Tables 5-6.

Table 5. Impact of Democracy Levels on ASI Countries Using the Bivariate Model

\begin{tabular}{ccccc}
\hline \multirow{2}{*}{ Indices } & $\begin{array}{c}\text { All analysed } \\
\text { countries }\end{array}$ & \multicolumn{3}{c}{ Segments of Democratic Profiles with ACSI Levels } \\
\cline { 3 - 4 } & 0.19 & 1 & 2 & 3 \\
\hline Coefficient at the & $(0.00)$ & 0.087 & 0.41 & 0.42 \\
regressor & 0.45 & $0.02)$ & $(0.00)$ & $(0.00)$ \\
R2 & 0.5 & 0.48 & 0.53 \\
\hline
\end{tabular}

Source: it is calculated by the author 
The empirical results of the proposed models (bivariate and multivariate) confirmed the statistically significant influence of democratic profiles on the ASI level.

Table 6. Influence of democracy level on ASI countries using the multivariate model

\begin{tabular}{|c|c|c|c|c|c|c|c|c|}
\hline \multirow{2}{*}{$\begin{array}{c}\text { SEGMENTS } \\
\text { Indices }\end{array}$} & \multicolumn{4}{|c|}{ ALL COUNTRIES } & \multicolumn{4}{|c|}{ SEGMENT 1} \\
\hline & $\mathrm{D}$ & A & $\mathrm{P}$ & GDP & $\mathrm{D}$ & A & $\mathrm{P}$ & GDP \\
\hline Coefficient at regressor & $\begin{array}{c}0.11 \\
(0.00)\end{array}$ & $\begin{array}{c}0.19 \\
(0.00)\end{array}$ & $\begin{array}{l}-0.03 \\
(0.96)\end{array}$ & $\begin{array}{c}0.93 \\
(0.00)\end{array}$ & $\begin{array}{c}0.09 \\
(0.00)\end{array}$ & $\begin{array}{c}0.13 \\
(0.08)\end{array}$ & $\begin{array}{c}0.03 \\
(0.76)\end{array}$ & $\begin{array}{c}1.03 \\
(0.00)\end{array}$ \\
\hline $\mathrm{R} 2$ & \multicolumn{4}{|c|}{0.83} & \multicolumn{4}{|c|}{0.7} \\
\hline SEGMENTS & \multicolumn{4}{|c|}{ SEGMENT 2} & \multicolumn{4}{|c|}{ SEGMENT 3} \\
\hline Indices & $\mathrm{D}$ & A & $P$ & GDP & $\mathrm{D}$ & A & $\mathrm{P}$ & GDP \\
\hline Coefficient at regressor & $\begin{array}{c}0.04 \\
(0.29)\end{array}$ & $\begin{array}{c}0.36 \\
(0.00)\end{array}$ & $\begin{array}{l}-1.15 \\
(0.08)\end{array}$ & $\begin{array}{c}0.91 \\
(0.00)\end{array}$ & $\begin{array}{c}0.08 \\
(0.03)\end{array}$ & $\begin{array}{c}0.34 \\
(0.00)\end{array}$ & $\begin{array}{c}-0.12 \\
(0.15)\end{array}$ & $\begin{array}{c}0.87 \\
(0.00)\end{array}$ \\
\hline R2 & \multicolumn{4}{|c|}{0.79} & \multicolumn{4}{|c|}{0.81} \\
\hline
\end{tabular}

$\mathrm{D}$ - level of democracy; R2 is the determination coefficient; the statistical significance of the respective parameters at $1 \%$ and $5 \%$ levels is indicated in the parentheses.

Source: it is calculated by the author

Thus, the transition of Ukraine from the group of countries with authoritarian and transitional regimes (segment 1) to imperfect democracy regime (segment 2) will ensure the increase of ASI by 0.41 points (by the bivariate model), provided that the level of democracy is increased by one point; 0.91 points if GDP increases by one point; 0.36 points, if the agricultural land area increases. However, the population is not a statistically significant factor of influence (more than 0.05 ) on ASI in any of the segments of democratic profiles.

\section{Discussion}

According to the results of the systematization of the existing incentives and instruments system to support the sustainable development of the agricultural sector in EU countries, the author proposes a set of ecological and economic instruments to stimulate the sustainable development of the native agricultural sector of the economy. So the main environmental and economic instruments are:

- the support of the market price by controlling the volume of imported products through tariff quotas, equity participation, tax breaks and export subsidies;

- differentiated payment system - the establishment of different level of payments for agricultural producers, depending on the level of compliance with its environmental standards;

- risk management and natural disaster insurance - state subsidizing of losses of agricultural producers, tax holidays, preferential terms of crediting, support and consulting services of producers from the agricultural sector of the economy, possible losses insurance, joint agricultural insurance programs;

- environmental funds - formation of a fund to reduce carbon emissions, to decrease the environmental tax on environmentally friendly agricultural products;

- investments in the rural development - investment support for rural infrastructure development, support and development of agricultural business;

- innovation and education - formation of agricultural research corporations, agro-research centres and laboratories, consulting on the insurance of agricultural enterprises, training in writing and submitting grant applications for additional funding.

It should be noted that the results of the foreign experience analysis regarding the motivation of the sustainable development of the agricultural sector to promote the latest programs and tools prove that such programs as AgriRisk; 
AgriScience; AgriInnovate; AgriMarketing have become widespread. In addition, native experts and stakeholders define the necessity to develop a training system for GAP (Good Agricultural Practices) certification procedures. The European integration processes require the adaptation of the national provision on the labelling and standardization of agricultural products in accordance with EU requirements.

\section{Acknowledgements}

This research was funded by the grant from the Ministry of Education and Science of Ukraine (Nos. g/r 0117U003932).

\section{References}

Acemoglu, D., Naidu, S., Restrepo, P., \& Robinson, J. A. (2019). Democracy does cause growth. Journal of Political Economy, 127(1), 47-100.

Afoaku, O. G. (2005). Linking democracy and sustainable development in Africa. Sustainable Development in Africa, 23-56.

Allen, M. W., \& Wilson, M. (2005). Materialism and food security. Appetite, 45(3), 314-323.

Altieri, M. A. (2018). Agroecology: the science of sustainable agriculture. CRC Press.

Anderson, K. (1995). Lobbying incentives and the pattern of protection in rich and poor countries. Econ. Dev. Cult. Change, 43(2), 401-423.

Awokuse, T. O., \& Xie, R. (2015). Does agriculture really matter for economic growth in developing countries?. Canadian Journal of Agricultural Economics/Revue canadienne d'agroeconomie, 63(1), 77-99.

Baklouti, N., \& Boujelbene, Y. (2018). The nexus between democracy and economic growth: evidence from dynamic simultaneous-equations models. Journal of the Knowledge Economy, 9(3), 980-998.

Bilan, Y., Raišienè, A. G., Vasilyeva, T., Lyulyov, O., \& Pimonenko, T. (2019). Public governance efficiency and macroeconomic stability: Examining convergence of social and political determinants. Public Policy and Administration, 18(2), 241-255. https://doi.org/10.13165/VPA-19-18-2-05

Bilan, Y., Streimikiene, D., Vasylieva, T., Lyulyov, O., Pimonenko, T., \& Pavlyk, A. (2019). Linking between renewable energy, $\mathrm{CO} 2$ emissions, and economic growth: Challenges for candidates and potential candidates for the EU membership. Sustainability, 11(6). https://doi.org/10.3390/su11061528

Blaydes, L., \& Kayser, M. A. (2011). Counting Calories: Democracy and Distribution in the Developing World1. International Studies Quarterly, 55(4), 887-908. https://doi.org/10.1111/j.1468-2478.2011.00692.x

Bozkurt, E., Altiner, A., \& Toktaş, Y. (2018). Democracy and economic growth: evidence from emerging market economies. Electronic Turkish Studies, 13(14).

de Gorter, H., \& Swinnen, J. (2002). Political economy of agricultural policies. In Gardner, B., \& Rausser, G. (Eds.), The Handbook of Agricultural Economics (pp. 2073-2123). Amsterdam, Elsevier Science.

De Haan, J., \& Siermann, C. L. J. (1996). New Evidence on the Relationship Between Democracy and Economic Growth. Public Choice, 86, 175-198.

Dkhili, H. (2018). Environmental performance and institutions quality: evidence from developed and developing countries. Marketing and Management of Innovations, 3, 333-244. https://doi.org/10.21272/mmi.2018.3-30

Dkhili, H., \& Dhiab, L. B. (2019). Environmental Management Efficiency of GCC Countries: Linking Between Composite Index of Environmental Performance, Socio-Political and Economic Dimensions. Marketing and Management of Innovations, 1, 57-69. https://doi.org/10.21272/mmi.2019.1-05

Feng, Y. (1997). Democracy, political stability and economic growth. British Journal of Political Science, 27(3), 391-418.

Freedom in the World Data and Resources. (2018). Freedom House. Retrieved from https://freedomhouse.org/report/methodology-freedom-world-2018

Hackett, M., Melgar-Quiñonez, H., Taylor, C. A., \& Uribe, M. C. A. (2010). Factors associated with household food security of participants of the MANA food supplement program in Colombia. Archivos latinoamericanos de nutrición, 60(1), 42.

Harris, K. (2014). Bread and freedom: Linking democracy and food security in Sub-Saharan Africa. African Studies Quarterly, 15(1), 13. 
Henisz, W. J. (2000). The institutional environment for economic growth. Econ. Polit., 12, 1-31.

Kaiser, L. L., Lamp, C. L., Johns, M. C., Sutherlin, J. M., Harwood, J. O., \& Melgar-Quiñonez, H. R. (2002). Food security and nutritional outcomes of preschool-age Mexican-American children. Journal of the American Dietetic Association, 102(7), 924-929.

Kim, N. S., \& Heshmati, A. (2019). The Relationship between Economic Growth and Democracy: Alternative Representations of Technological Change. In Panel Data Econometrics (pp. 885-929). Academic Press.

Leblang, D. A. (1996). Property rights, democracy and economic growth. Political Research Quarterly, 49(1), 5-26.

Lewontin, R. C. (1974). The analysis of variance and the analysis of causes. Am J Hum Genet., 26, 400-11.

Li, S., Tian, Y., Wu, K., Ye, Y., Yu, J., Zhang, J., ... Harberd, N. P. (2018). Modulating plant growth-metabolism coordination for sustainable agriculture. Nature, 560(7720), 595.

Mathonnat, C., \& Minea, A. (2018). Forms of democracy and economic growth volatility. Economic Modelling. https://doi.org/10.1016/j.econmod.2018.07.013

Maxwell, D., Ahiadeke, C., Levin, C., Armar-Klemesu, M., Zakariah, S., \& Lamptey, G. M. (1999). Alternative food-security indicators: revisiting the frequency and severity ofcoping strategies. Food policy, 24(4), 411-429.

Nelson, M. A., \& Singh, R. D. (1998). Democracy, Economic Freedom, Fiscal Policy, and Growth in LDCs: A Fresh Look. Economic Development and Cultural Change, 46(4), 677-697.

Olper, A., Fałkowski, J., \& Swinnen, J. (2013). Political reforms and public policy: evidence from agricultural and food policies. The World Bank Economic Review, 28(1), 21-47.

Pérez-Escamilla, R. (2017). Food security and the 2015-2030 sustainable development goals: From human to planetary health: Perspectives and opinions. Current Developments in Nutrition, 1(7), p. e000513.

Polity IV. (2018). Centre for Systemic Peace. Retrieved from http://www.systemicpeace.org/inscrdata.html

Prasad, R., Bhattacharyya, A., \& Nguyen, Q. D. (2017). Nanotechnology in sustainable agriculture: recent developments, challenges, and perspectives. Frontiers in Microbiology, 8, 1014.

Quinn, D. P., \& Woolley, J. T. (2001). Democracy and national economic performance: the preference for stability. Am. J. Polit. Sci., 45, 634-657.

Rodrik, D. (1999). Where did all the growth go? External shocks, social conflict and growth collapses. J. Econ. Growth, 4, 385-412.

Rodrik, D. (2000). Participatory politics, social cooperation and economic stability. Am. Econ. Rev., 90, 140-144.

Rossignoli, D., \& Balestri, S. (2017). Food security and democracy: do inclusive institutions matter?. Canadian Journal of Development Studies / Revue Canadienne D'études Du Développement, 39(2), 215-233. https://doi.org/10.1080/02255189.2017.1382335

Swinnen, J., \& Vandevelde, S. (2018). The Political Economy of Food Security and Sustainability. Reference Module in Food Science. https://doi.org/10.1016/b978-0-08-100596-5.22328-7

Unit, E. I. (2018). The Economist Intelligence Unit's Democracy Index. Retrieved from https://infographics.economist.com

Vasylieva, T., Lyulyov, O., Bilan, Y., \& Streimikiene, D. (2019). Sustainable economic development and greenhouse gas emissions: The dynamic impact of renewable energy consumption, GDP, and corruption. Energies, 12(17). https://doi.org/10.3390/en12173289

World Bank (2019). World Development Indicators database. Retrieved 12 June 2019, from http://databank.worldbank.org/data/reports.aspx?source=world-development-indicators

Yang, Z., Wang, D., Du, T., Zhang, A., \& Zhou, Y. (2018). Total-Factor Energy Efficiency in China’s Agricultural Sector: Trends, Disparities and Potentials. Energies, 11(4), 853.

Yevdokimov, Y., Melnyk, L., Lyulyov, O., Panchenko, O., \& Kubatko, V. (2018). Economic freedom and democracy: determinant factors in increasing macroeconomic stability. Problems and Perspectives in Management, 16(2), 279-290. https://doi.org/10.21511/ppm.16(2).2018.26 